\title{
Towards Standardization of Life-Cycle Metrics for Biofuels: Greenhouse Gas Emissions Mitigation and Net Energy Yield
}

\author{
Adam J. Liska and Kenneth G. Cassman* \\ Nebraska Center for Energy Sciences Research, Department of Agronomy and Horticulture, \\ University of Nebraska-Lincoln, Lincoln, NE 68583-0724, USA
}

\begin{abstract}
Despite a rapid worldwide expansion of the biofuel industry, there is a lack of consensus within the scientific community about the potential of biofuels to reduce reliance on petroleum and decrease greenhouse gas (GHG) emissions. Although life cycle assessment provides a means to quantify these potential benefits and environmental impacts, existing methods limit direct comparison within and between different biofuel systems because of inconsistencies in performance metrics, system boundaries, and underlying parameter values. There is a critical need for standardized life-cycle methods, metrics, and tools to evaluate biofuel systems based on performance of feedstock production and biofuel conversion at regional or national scales, as well as for estimating the net GHG mitigation of an individual biofuel production system to accommodate impending GHG-intensity regulations and GHG emissions trading. Predicting the performance of emerging biofuel systems (e.g., switchgrass cellulosic ethanol) poses additional challenges for life cycle assessment due to lack of commercial-scale feedstock production and conversion systems. Continued political support for the biofuel industry will be influenced by public perceptions of the contributions of biofuel systems towards mitigation of GHG emissions and reducing dependence on petroleum for transportation fuels. Standardization of key performance metrics such as GHG emissions mitigation and net energy yield are essential to help inform both public perceptions and public policy.
\end{abstract}

Keywords: Life Cycle Assessment, Biofuel, Corn-Ethanol, Cellulosic Ethanol, Biodiesel, Net Energy, Greenhouse Gas Emissions, Emissions Trading, Sustainability.

\section{CONTENTS}

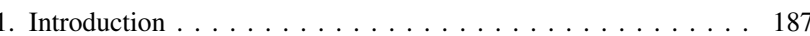

1.1. Life Cycle Assessment . . . . . . . . . . . . . . . . . . . . 188

1.2. Net Energy Metrics . . . . . . . . . . . . . . . . . . . . . . 189

2. Life Cycle Assessment of Established Ethanol and

Biodiesel Systems . . . . . . . . . . . . . . . . . . . . . . . . 189

2.1. Sugar-Ethanol . . . . . . . . . . . . . . . . . . . . . . . 190

2.2. Starch-Ethanol . . . . . . . . . . . . . . . . . . . . . . . 190

2.3. Vegetable Oil-Biodiesel . . . . . . . . . . . . . . . . 192

2.4. Comparison of Established Biofuel Systems . . . . . . . 193

3. Advances in the Performance of Corn

Grain-Ethanol Systems . . . . . . . . . . . . . . . . . . . . . . . 194

3.1. Greenhouse Gas Emission Reductions

Accounting and Trading . . . . . . . . . . . . . . . . 195

4. Life Cycle Assessment of Emerging Biofuel Systems . . . . . 196

4.1. Cellulosic Ethanol; Biochemical Conversion . . . . . . . . 196

4.2. Fischer-Tropsch Biofuel . . . . . . . . . . . . . . . . . 198

5. Linkages Among Biofuel System Performance Metrics . . . . 198

6. Standardization of Life Cycle Assessment Metrics

for Biofuel Systems

*Author to whom correspondence should be addressed.

Email: kcassman1@unl.edu
7. Conclusion . . . . . . . . . . . . . . . . . . 200

Acknowledgments . . . . . . . . . . . . . . 201

References .......................... 201

\section{INTRODUCTION}

The rapid development and expansion of diverse biofuel production systems are transforming global agriculture. Large-scale biofuel industries are being promoted to decrease reliance on petroleum in response to an abrupt rise in oil prices and to develop transportation fuels that reduce greenhouse gas (GHG) emissions $\left(\mathrm{CO}_{2}, \mathrm{CH}_{4}\right.$, and $\mathrm{N}_{2} \mathrm{O}$ ) compared to petroleum-derived gasoline and diesel fuel. ${ }^{1}$ Biofuels also foster economic development in rural communities, and when used as a gasoline additive, ethanol biofuel can reduce harmful emissions of several pollutants. ${ }^{2}$ Currently, biofuel production capacity is expanding most rapidly in the USA, Brazil, Europe, and several Southeast Asian countries where agricultural feedstocks are available. ${ }^{3}$ 
Despite these compelling benefits, there is disagreement concerning the energy efficiency of biofuels and the net impact on GHG emissions. Biofuel systems are composed of three sub-systems:

(1) a crop production system that provides feedstock,

(2) a biorefinery that converts the agricultural products to liquid fuels, and

(3) the utilization of co-products.

Life cycle assessment (LCA) provides the basis for quantifying the environmental impact of these systems in their entirety, from seed to biofuel. Current disagreements about the performance of biofuels rest on different approaches and assumptions used by the investigators performing these assessments. ${ }^{4}$ Standardized LCA methods and agreement on the most relevant metrics for assessing different biofuel systems are needed to forge a consensus in the scientific community, general public, and industry about the contributions to both petroleum replacement potential and environmental goals. Such a consensus would help advance public policy initiatives to encourage development of "green" biofuel industries.

The Energy Independence and Security Act of 2007 requires that life-cycle GHG emissions of corn grainethanol, cellulosic ethanol, and advanced biofuels are evaluated to ensure they meet 20\%,60\%, and 50\% GHG emissions reductions relative to gasoline, respectively. Moreover, producers will need to verify life-cycle GHG reductions to import their biofuel into regulated markets that require GHG certification, such as under the Low Carbon Fuel Standard in California. ${ }^{5}$ A biofuel certification process based on LCA would enable the biofuel industry to participate in emerging markets for GHG emissions trading, which could provide additional industry revenue and encourage investment in GHG emissionsreducing technologies. Life-cycle methods are also crucial for ex ante evaluation of alternative technologies to improve the performance of new biorefinery designs, and to assist in research prioritization for development of new feedstock crops and production systems.

Given the need for standardized methods and scientific consensus, this article reviews life-cycle methods, assumptions, and metrics used to assess biofuel systems, compares several studies to identify inconsistencies, and proposes approaches for more accurate and standardized LCA methodology and applications for biofuel systems. We will focus on two categories of biofuels systems: (i) established, large-scale systems, with a focus on stateof-the-art corn grain-ethanol systems, and (ii) experimental systems under development but not yet deployed on a commercial scale. Systems are evaluated for their impacts on net GHG emissions for mitigating climate change, and net energy yield as an indicator of contributions to energy self-sufficiency, land requirements, and potential competition with food production.

\subsection{Life Cycle Assessment}

Existing life cycle assessments of biofuel systems can be classified into three types:

(a) life-cycle energy (LCE) assessment,

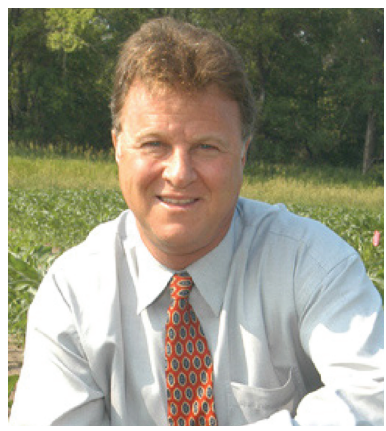

Dr. Cassman is Director of the Nebraska Center for Energy Sciences Research at the University of Nebraska, and the Heuermann Professor of Agronomy. In previous positions, Dr. Cassman has worked as a research agronomist in the Amazon Basin of Brazil, Egypt's Nile Valley, and at the International Rice Research Institute in the Philippines. Academic appointments include seven years on the faculty at the University of California-Davis, and eight years as Head of the Department of Agronomy at the University of Nebraska. His research, teaching, and extension efforts have focused on ensuring local and global food security while conserving natural resources and protecting environmental quality. Current research examines the environmental impact of biofuel systems. Dr. Cassman received a Ph.D. (1979) from the University of Hawaii's College of Tropical Agriculture, and a BS degree in Biology from the University of California, San Diego (1975). He is a Fellow of the American Association for the Advancement of Science, the American Society of Agronomy, the Crop Science Society of America, and the Soil Science Society of America.

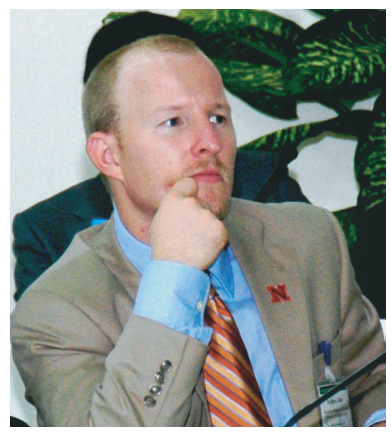

Adam Liska completed a Ph.D. in biology at the Max Planck Institute of Molecular Cell Biology and Genetics in Dresden, Germany, and obtained a B.S. in biochemistry and biology at the University of Nebraska. He is currently a post-doctoral research associate in the Department of Agronomy and Horticulture at the University of Nebraska. Before involvement in bioenergy research, he worked on mass spectrometry-based proteomics. He is currently working on development of life-cycle assessment software for certification of net energy efficiency and greenhouse gas mitigation potential of biofuel systems to help implement state, regional, and national low-carbon fuel standards. 
(b) life-cycle GHG (LCG) assessment, or

(c) multi-criteria LCA. The LCE and LCG studies are closely related because fossil fuel use has a large influence on both net energy efficiency and GHG emissions.

An LCA is a "compilation and evaluation of the inputs, outputs, and the potential environmental impacts of a product system throughout its lifecycle." ${ }^{\circ}$ The International Organization of Standardization (ISO) has developed LCA protocols to certify that a given production system does not have environmental impacts that exceed accepted thresholds. ${ }^{6,7}$ As such, LCA is recognized as a seminal tool for assessing the environmental sustainability of biofuel systems. ${ }^{8}$ Although ISO standards can be used for analysis of biofuel systems, direct comparison among different biofuels or between systems operating at different spatial and temporal scales are not appropriate unless a common LCA framework is used. Therefore, the goals, performance metrics, and objectives of an LCA study determine the demarcation of system boundaries, and the specification of boundaries has a major influence on LCA results.

For instance, all crop-based biofuels require land for feedstock production such that increased demand for these crops may cause land use change. ${ }^{9}$ This "indirect effect" has largely been outside the system boundaries of previous LCA studies. Direct land use change results from expansion of crop area within a given country to produce a specific feedstock crop needed to meet the increased demand for that crop due to biofuel production within that country. Such expansion can come at the expense of shifts in area from other crops, from land currently in a conservation reserve program, or from conversion of land in natural ecosystems (e.g., forest, wetlands, or grasslands), and any net GHG emissions that result from this land use change should be considered additional emissions in the biofuel life-cycle. Indirect land use change is caused by global expansion of crop area by conversion of land not currently used for agriculture because of higher commodity prices on international markets for sugar, starch, oilseed, or biomass crops used as biofuel feedstock. Both types of land use change can have a large influence on net GHG emissions from these systems, ${ }^{10,11}$ although the assumptions used in these recent analyses may overstate the impact by a considerable margin. Further research is needed to more accurately estimate the influence of biofuels on land use change and the associated environmental impact attributable to biofuels.

\subsection{Net Energy Metrics}

Biofuels are derived from renewable solar energy captured by plant photosynthesis. Considerable attention has been given to quantifying the net renewable energy yield over the life-cycle of biofuel systems that use different conversion technologies and feedstock crops. The net renewable energy yield is defined as the gross energy yield of a biofuel production system minus the non-renewable fossil energy inputs used in producing the feedstock and its conversion to biofuel and co-products. Net energy metrics, however, have been criticized because they do not account for the different values and utility of the fossil fuels used in biofuel production or of the final biofuel product. ${ }^{12}$

Net energy output can be quantified in three ways:

(1) Net Energy Ratio (NER), which is a unitless ratio of the energy output divided by the energy input;

(2) Net Energy Value (NEV) is the energy output minus input, in megajoules per liter $\left(\mathrm{MJ} \mathrm{L}^{-1}\right)$;

(3) Net Energy Yield (NEY) is the energy output minus input on a crop feedstock production area basis, usually in units of gigajoules per hectare $\left(\mathrm{GJ} \mathrm{ha}^{-1}\right)$.

All three measures evaluate the energy inputs and outputs for the entire biofuel system, including crop production, biofuel conversion, and co-product processing and utilization. While NER and NEV typically receive most attention because they are thought to provide a surrogate for GHG emissions mitigation, land use efficiency, and petroleum consumption, ${ }^{4,13}$ they are intensity factors that do not represent the "energy productivity" of a system on a land-area basis. In fact, biofuel systems with large NER and NEV values can have relatively small NEY. For example, soybean-biodiesel has been shown to have higher NER and NEV than corn grain-ethanol, but it has $23 \%$ smaller NEY, ${ }^{14}$ which means that soybean biodiesel systems require more land to produce the same amount of net energy. In contrast, NEY combines energy efficiency and productivity into one value, ${ }^{15}$ and therefore it is a more suitable metric for comparisons of different biofuel systems when the objective is to reduce dependence on imported petroleum and minimize the competition for land which could also be used for food production. ${ }^{9}$

\section{LIFE CYCLE ASSESSMENT OF ESTABLISHED ETHANOL AND BIODIESEL SYSTEMS}

Organic materials can be converted to liquid fuel by a number of processes depending on feedstock properties. The world's largest biofuel industries rely on fermentation of plant carbohydrates to ethanol. ${ }^{16}$ Ethanol can be made from three sources of carbohydrate:

(1) simple carbohydrates, (e.g., glucose and sucrose), (2) polymeric storage carbohydrates that are easily broken-down to simple carbohydrates (e.g., starch), and (3) structural carbohydrate polymers that are largely resistant to conversion to simple carbohydrates (e.g., lignocellulose).

Ethanol is produced primarily using sugarcane (Saccharum sp. L.) as a source of simple sugars in Brazil or corn (Zea mays L.) grain as a source of starch in the USA. In contrast, large-scale commercial production 
of ethanol from lignocellulosic sources has yet to be

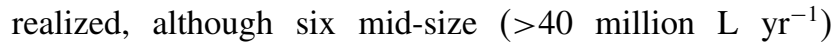
commercial cellulosic ethanol biorefineries are under construction with support from the US Department of Energy (http://www.energy.gov/news/4827.htm), in addition to several smaller facilities. ${ }^{17}$ In addition to ethanol, biodiesel is produced from oilseeds from a number of plant species. For each of these systems, LCA of the energy efficiency and GHG balance can be performed and results compared if standardized methods are used.

\subsection{Sugar-Ethanol}

Sugar crops used for ethanol production include sugarcane, sugar beet (Beta vulgaris L.), and sweet sorghum (Sorghum bicolor L.). Of existing large-scale biofuel systems, sugarcane-ethanol is considered the most efficient and sustainable. ${ }^{18}$ As a C-4 crop, sugarcane has high radiation use efficiency and transforms photosynthate into readily fermentable sucrose, which accumulates in the plant's stalk during growth. Contrary to starch- and cellulosicethanol production, sugarcane-ethanol processing does not require energy expenditure to depolymerize the carbohydrate into simple sugars for fermentation because sucrose is a disaccharide that can be fermented directly. The remaining crop residues, called bagasse, are burned to provide the required heat for fermentation and distillation, and also to generate electricity. ${ }^{19}$ Therefore, sugarcane-ethanol systems have a high NEY and the potential for a large reduction in GHG emissions compared to gasoline..$^{20,21}$

The NER of sugarcane-ethanol has been estimated at $3.1-10.2 .^{20-22}$ The relatively low NER estimate of 3.1 , however, results from an overestimation of diesel fuel use in crop production and harvesting; substitution of a more representative diesel fuel use value gives an NER range of 8.3-10.2. ${ }^{19}$ An extensive LCA of the Brazilian sugarcaneethanol industry, which produced about 16 billion liters (GL) in 2005, evaluated the GHG balance, competition with food, impacts on biodiversity, economic stability, impact on soil erosion, and water-use practices, among other factors. ${ }^{19}$ Based on these biophysical, economic, and social metrics, the authors concluded that the industry has the potential for long-term sustainability.

Sugar beet accumulates sucrose in belowground tubers, which are used to produce ethanol in Europe although on a much smaller scale than for sugarcane-ethanol in Brazil. It is not favored as a biofuel feedstock because, as a crop grown in temperate climates, it is harvested in the fall and winter as a fresh tuber and is difficult to store without losses. In contrast, sugarcane can be harvested over a longer period because it is grown in the tropics. Only a few studies have examined the LCE of sugar beet-ethanol. The authors of one study used a novel metric for system evaluation called "energy renewability efficiency," which is the ratio of NEV to the heating value of ethanol. After recalculation, the study estimated a NER of 1.6 for this European sugar beet biofuel system. ${ }^{23}$

Sweet sorghum is a third source of fermentable sugar for biofuel production, and like sugarcane, it accumulates fermentable sugar in its stalk. The crop was grown extensively in the Midwestern and Southeastern USA as a syrup source, with peak production in the 1880 's. ${ }^{24}$ To date, sweet sorghum has not been used as an ethanol feedstock in large-scale production systems. However, researchers in India and the USA are investigating its potential as a biofuel crop in dryland regions due to its reduced water requirement compared to sugarcane ${ }^{25}$ and its greater drought tolerance compared to corn.

\subsection{Starch-Ethanol}

Grain crops such as maize, sorghum, wheat (Triticum $s p$. L.), and root and tuber crops such as cassava (Manihot esculenta L.) can be used for starch-based ethanol production. Of these potential starch crops, the USA corn grain-ethanol industry is most highly developed, ${ }^{26}$ reaching $25 \mathrm{GL}$ in 2007. Before starch can be fermented into ethanol, it must be partially degraded into soluble dextrins by a process called liquefaction. ${ }^{16}$ The dextrins are then hydrolyzed into fermentable sugars using enzymes in a process called saccharification. These breakdown processes require heat, ${ }^{27}$ which reduces both the net energy yield and the GHG mitigation potential compared to sugarethanol systems.

\subsubsection{Corn Grain-Ethanol, LCE Assessments}

Recent LCE assessments have analyzed the energy efficiency of corn grain-ethanol production with conflicting results. Some estimate that corn grain-ethanol requires more /energy input than is gained from the ethanol and co-products. ${ }^{28,29}$ Other studies report positive net energy. ${ }^{22,30-32}$ The LCE of corn grain-ethanol considers the energy used for feedstock production and harvesting, including fossil fuels (primarily diesel) for field operations and electricity for irrigation and grain drying. Crop production energy expenditure also includes upstream costs for the production of fertilizer, pesticides, seed, and the depreciable energy cost used to manufacture the farm machinery used in crop production. Energy use in ethanol production includes transportation of grain to the biorefinery, conversion to biofuel, and co-product processing and utilization. Energy used for production of materials and construction of the biorefinery facility must also be included and prorated over the life-time of the facility. ${ }^{33}$

Farrell et al. (2006) recently reconciled the divergent results in previous published reports in an analysis of six prominent studies. ${ }^{4,22,28-32}$ The standard framework equalized system boundaries, most of the input energy parameter values, and conversion efficiencies across the studies. Based on this approach, corn grain-ethanol was found to 
Table I. Life cycle assessments of corn grain-ethanol.

\begin{tabular}{|c|c|c|c|c|c|c|c|}
\hline Study & $\begin{array}{c}\text { Analysis } \\
\text { types }\end{array}$ & $\begin{array}{c}\text { Grain } \\
\text { processing }\end{array}$ & $\begin{array}{l}\text { Biorefinery } \\
\text { energy source }\end{array}$ & $\begin{array}{l}\text { Co-product } \\
\text { processing }\end{array}$ & $\begin{array}{c}\text { Co-product } \\
\text { credit }(\mathrm{MJ} / \mathrm{L})\end{array}$ & $\begin{array}{l}\text { Geographical } \\
\text { scale }\end{array}$ & $\begin{array}{l}\text { Net energy } \\
\text { ratio }\end{array}$ \\
\hline Farrell et al. 2006 & LCE/LCG & $\begin{array}{c}\text { Wet and dry } \\
\text { mill avg. }\end{array}$ & Coal and nat. gas & Mostly dried $\mathrm{DG}^{a}$ & 4.13 & USA-corn belt & 1.2 \\
\hline Hill et al. 2006 & LCE/ LCG & Dry mill & Coal and nat. gas & Average $^{a}$ & 4.31 & USA-corn belt & 1.3 \\
\hline Oliviera et al. 2005 & $\mathrm{LCE} / \mathrm{LCG}$ & $\begin{array}{c}\text { Wet and dry } \\
\text { mill avg. }\end{array}$ & Coal and nat. gas & Mostly dried $\mathrm{DG}^{a}$ & $0(4.13)^{b}$ & USA-corn belt & $1.1(1.2)^{b}$ \\
\hline Pimentel and Patzek 2005 & LCE & $\mathrm{ns}$ & ns & ns & $0(1.86)^{b}$ & USA-average & $0.8(0.9)^{b}$ \\
\hline Patzek 2004 & LCE & Wet mill & ns & ns & $0(4.13)^{b}$ & - & $0.8(0.9)^{b}$ \\
\hline Shapouri et al. 2004 & LCE & $\begin{array}{c}\text { Wet and dry } \\
\text { mill avg. }\end{array}$ & Coal and nat. gas & Mostly dried $\mathrm{DG}^{a}$ & 7.31 & USA-corn belt & $1.5(1.4)^{b}$ \\
\hline Graboski 2002 & LCE & $\begin{array}{c}\text { Wet and dry } \\
\text { mill avg. }\end{array}$ & Coal and nat. gas & ns & 4.13 & USA-corn belt & $1.2(1.1)^{b}$ \\
\hline Wang 1999 & LCG & $\begin{array}{l}\text { Wet and dry } \\
\text { mill avg. }\end{array}$ & ns & ns & 4.04 & 16 states & $1.4(1.3)^{b}$ \\
\hline Kim and Dale 2005 (38) & LCG & $\begin{array}{l}\text { Wet or dry } \\
\text { mill }\end{array}$ & Coal and nat. gas & Dried DG & $\begin{array}{l}\text { Range, GHG } \\
\text { credit }\end{array}$ & $\begin{array}{l}\text { Several } \\
\text { counties in } \\
\text { IA and IL }\end{array}$ & ns \\
\hline Kim and Dale 2005 (115) & LCA & Wet mill & ns & $\begin{array}{l}\text { Standard wet } \\
\text { mill products } \\
\text { genta to: }\end{array}$ & $\begin{array}{l}\text { Aggregate } \\
\text { credit for } \\
\text { each metric }\end{array}$ & $\begin{array}{l}\text { Scott county, } \\
\text { IA }\end{array}$ & ns \\
\hline
\end{tabular}

${ }^{a}$ Wet and dry distiller's grains in some proportion. ${ }^{b}$ Adjusted in Farrell et al. (2006) to conform to a standard framework for key inputs and outputs, energy values, and system boundaries. $\mathrm{ns}=$ not specified.

have a small, but positive NER of 1.2 (Table I). A later study using a similar protocol found that corn grainethanol had an NER of $1.25 .{ }^{14}$ Despite the estimate of a positive NER in this comprehensive attempt to standardize results from different studies, some still criticize the efficiency of corn grain-ethanol by Farrell et al. as too low to warrant government subsidies for future development. ${ }^{34}$

A common feature of most LCE assessments is that they evaluate the efficiency of the corn grain-ethanol industry at a regional or national scale, which requires use of average crop and biorefinery performances. For example, the most prominent recent studies used Corn Belt averages for crop yields and production input rates based on state averages prorated by corn production totals in each state. ${ }^{32}$ Some studies have used the average performance for dry mill or wet mill processing of the corn feedstock exclusively, while others have used an arithmetic average efficiency based on both mill types from a 2001 industry survey (Table I). However, according to this survey, wet mill ethanol plants used $11 \%$ more thermal energy than dry mill plants, which represents a significant portion of lifecycle energy use. ${ }^{32}$ In addition, most previous studies have used a mixture of energy inputs for the biorefinery (coal and natural gas) and the average proportion of dried versus wet co-products. System boundaries also varied because not all studies provided a co-product energy credit, although this was accounted for by Farrell et al. (Table I).

Although co-product energy credits account for $\sim 15-25 \%$ of gross energy output in corn-ethanol systems, different methods have been used for estimating co-product credits. Kim and Dale (2002) use an allocation procedure to distribute the environmental burdens of the production process to various co-products. ${ }^{35}$ An alternative approach is the displacement method which assumes that co-products from corn grain-ethanol production substitute for other products that require energy for their production. For corn grain-ethanol, distiller's grains co-product represents the unfermentable components in grain, which include protein, oil, and cellulosic seed coat material. As such, distiller's grains represent a nutritious animal feed for ruminants, and can substitute for soybean meal or corn and urea in cattle diets. ${ }^{36}$ Therefore, most LCE assessments give a displacement energy credit for this co-product. ${ }^{4}$

The aggregate approach taken in these studies does not evaluate the performance of an individual ethanol biorefinery, its corn feedstock supply, and its method of utilization of co-products. Likewise, they do not account for the improved design and technologies of recently built ethanol biorefineries. In fact, USA corn grain-ethanol production is expanding so rapidly that a majority of the current production capacity now comes from biorefineries that have been built since 2003. Therefore, even the most recent published LCE studies of corn ethanol using an aggregate approach represent a "backward-looking" perspective to estimate the energy efficiency of the corn grain-ethanol industry as a whole, which is further discussed in Section 3.

\subsubsection{Corn Grain-Ethanol, LCG Assessments}

The output metric used to quantify GHG emissions, either per mile driven versus per liter of biofuel, has a significant effect on the resulting estimate of GHG mitigation. ${ }^{37}$ The most thorough GHG analysis of corn grain-ethanol estimated a net reduction in emissions (on a per mile driven basis) of 1\% for E10, 14-19\% for E85, and 19-25\% for E95 blends. ${ }^{30}$ On a volumetric basis (e.g., emissions per 
gallon or liter corrected for differences in energy content), the authors reported a $12-19 \%, 17-24 \%$, and a 21-27\% reduction in GHG emissions for E10, E85, and E95, respectively. Farrell et al. (2006) estimated that corn grain-ethanol reduces GHG emissions by $13 \%$ compared to gasoline (Fig. 1), and similar results were reported in another recent study. ${ }^{14}$ These estimates are based on the standard GHG emissions in the production life cycle for a MJ of gasoline versus a MJ of ethanol based on life-cycle fossil fuel emissions for the ethanol production system (including $\mathrm{N}_{2} \mathrm{O}$ emissions from nitrogen fertilizer applied to corn and transportation of the ethanol to a facility to blend with gasoline). These calculations assume that ethanol itself is GHG neutral because its carbon content is recycled from the atmosphere by the corn crop.

A more extensive LCG assessment of corn grain-ethanol production accounted for both fossil fuel used in the biofuel production and associated changes in soil carbon (C) stocks in corn fields that provided the biofuel feedstock. ${ }^{38}$ In this study, corn grain-ethanol production was reported to result in a $41-61 \%$ reduction in net GHG emissions compared to gasoline per $\mathrm{km}$ driven; soil $\mathrm{C}$ sequestration offset $\sim 230 \%$ of life-cycle fossil fuel emissions. However, the DAYCENT model used to estimate soil $\mathrm{C}$ dynamics may overestimate soil $\mathrm{C}$ sequestration and the associated life-cycle GHG emissions reduction. The CENTURY model, upon which

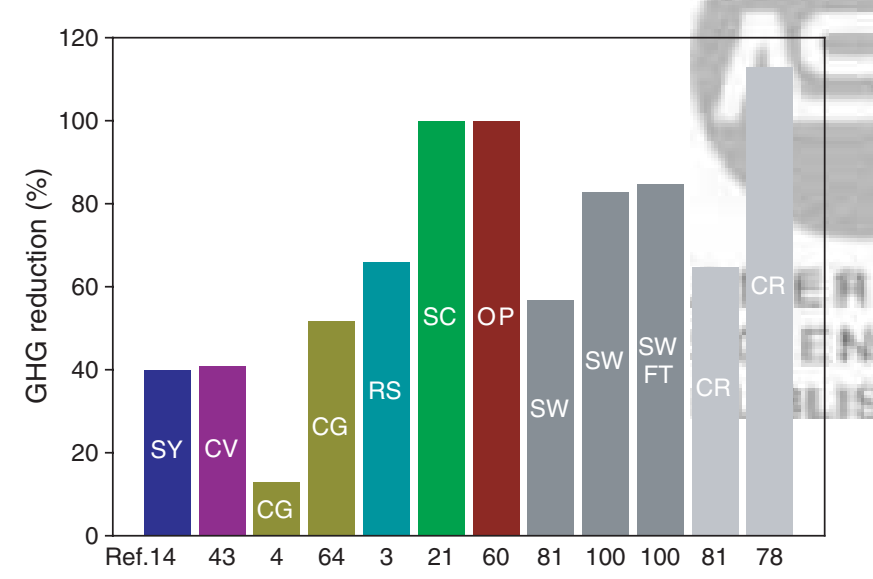

Fig. 1. Greenhouse gas (GHG) emissions reduction from biofuel systems compared to gasoline based on estimates published in the literature. Different values for the same biofuel crop reflect differences in energy efficiency parameters used in various components of the LCA. SY: soybean-biodiesel; CV: cassava-ethanol; CG: corn grain-ethanol; RS: rapeseed-biodiesel; SC: sugarcane-ethanol; OP: oil palm-biodiesel; SW: switchgrass cellulosic-ethanol; SW FT: switchgrass Fischer-Tropsch biofuel; CR: corn residue-cellulosic ethanol. Reference [64] cites biomass used for co-generation at the corn-ethanol biorefinery to replace electricity and natural gas or coal-derived energy inputs, which is estimated to reduce life-cycle GHG emissions. Reference [21] cites $\mathrm{CO}_{2}$ emissions reductions only. Reference [60] found significant carbon sequestration in oil palm plantations not associated with logging, and the high NER of oil palm-biodiese ${ }^{59}$ enables a preliminary estimate of at least $100 \%$ reduction in GHG emissions. Reference [3] cites $44-66 \%$ GHG reduction. Reference [81] cites reductions from a fuel blend (E85), as opposed to a pure biofuel. the DAYCENT model is based, was validated against data from long-term field studies that monitored changes in soil $\mathrm{C}$ only within the surface soil layer, which represents about one third of the entire root zone, and did not account for changes in soil bulk density. ${ }^{39,40}$ Recent detailed studies that measure changes in soil $\mathrm{C}$ within the entire root zone and also account for changes in soil bulk density have not found measurable net $\mathrm{C}$ sequestration in corn-based production systems with no-till management. ${ }^{41,42}$ Hence, the net impact of corn production on soil $\mathrm{C}$ content and associated life-cycle emissions remains highly uncertain. In contrast, conversion of land that has been in Conservation Reserve grass land for many years will result in substantial loss of accumulated soil organic matter and contribute to increased GHG emissions in the biofuel life cycle. ${ }^{10}$

\subsubsection{Cassava and Wheat}

To date, cassava and wheat have not been thoroughly evaluated by LCA. In one study of cassava-ethanol production, three metrics were used in the assessment: profitability, environmental impact, and energy efficiency. ${ }^{43}$ Despite costing $45 \%$ more to produce than gasoline, cassava-based E85 flex fuel vehicles used $40 \%$ less life-cycle fossil fuels and $78 \%$ less petroleum than gasoline. More detailed LCE assessments of cassava-ethanol in Thailand estimated energy efficiency similar to corn grain-ethanol. ${ }^{44}$

A recent LCA of a wheat-ethanol system estimated a reduction in fossil fuel use and net GHG emissions compared to gasoline. ${ }^{23}$ After recalculation of their metric, we estimate an NER of 1.9 for this wheat-ethanol system although this value is highly dependent on the specification of co-product energy credits.

\subsection{Vegetable Oil-Biodiesel}

Vegetable oil derived from oil crops such as rapeseed (Brassica napus L.), soybean (Glycine max L.), oil palm (Elaeis guineensis L.), and sunflower (Helianthus annuus L.) can be easily converted to biodiesel with appropriate properties for substitution of conventional petroleum-based diesel. ${ }^{45}$ Triglycerides are extracted from oilseeds and reacted with an alcohol (e.g., methanol or ethanol) in the presence of either an acid or base catalyst to produce fatty acid methyl- or ethyl-esters in a transesterification process. ${ }^{46}$ As of 2005, major biodiesel producers included Germany, (1.9 $\mathrm{GL} \mathrm{yr}^{-1}$ ), France (0.5), the USA $(0.3)$, and Italy $(0.2){ }^{47}$

\subsubsection{Rapeseed-Biodiesel}

Rapeseed is adapted to temperate climates and supports a large portion of Germany's biodiesel production. A number of life-cycle studies of rapeseed-biodiesel from the private-sector have estimated net GHG emissions reduction of $44-66 \%$ compared to conventional diesel fuel. ${ }^{3}$ 


\subsubsection{Soybean-Biodiesel}

The life-cycle energy efficiency and GHG emissions mitigation potential of soybean-biodiesel are relatively large compared to starch-based biofuels, in part because the biofuel conversion process is less energy intensive. Likewise, as a legume, soybean requires little $\mathrm{N}$ fertilizer because it can meet its $\mathrm{N}$ requirement from symbiotic $\mathrm{N}_{2}$ fixation by rhizobia in root nodules. A recent LCA of soybean-biodiesel estimated a NER of 1.9 and a reduction in GHG emissions of $41 \%,{ }^{14}$ supporting a previous study with similar results. ${ }^{48}$ In contrast, Pimentel and Patzek (2005) estimate that soybean-biodiesel has a negative NER, similar to their negative estimates of corn grain-ethanol energy efficiency. ${ }^{29}$ But Pimentel and Patzek include energy costs for labor, excessively high lime rates which are not consistent with average USA soybean production, and do not give an energy output credit for soybean meal and glycerol, two major co-products in the production of soybean-biodiesel. ${ }^{49}$

Despite high energy efficiency, the primary drawbacks of soybean-biodiesel systems are relatively small gross and net energy yields per area of crop production. Soybean seed yields are only $\sim 33 \%$ of corn grain yields in the USA and produce approximately a third of the liquid biofuel volume per unit mass of feedstock. ${ }^{14}$ After compensating for the energy content difference between biodiesel and ethanol, corn grain-ethanol systems yield four times more gross energy per hectare than soybean-biodiesel (Table II).

Table II. Average gross energy yield of ethanol and biodiesel biofuel systems by feedstock and country (top two producers for each biofuel crop).

\begin{tabular}{llccc}
\hline Crop & Country & $\begin{array}{c}\text { Yield } \\
\left(\mathrm{Mg} \mathrm{ha}^{-1}\right)\end{array}$ & $\begin{array}{c}\text { Biofuel } \\
\left(\mathrm{L} \mathrm{ha}^{-1}\right)\end{array}$ & $\begin{array}{c}\text { Energy } \\
\left(\mathrm{GJ} \mathrm{ha}^{-1}\right)\end{array}$ \\
\hline Oil palm $^{b}$ & Malaysia & 20.6 & 4736 & 155.8 \\
Oil palm $^{b}$ & Indonesia & 17.8 & 4092 & 134.6 \\
Sugarcane $^{e}$ & Brazil & 73.5 & 5475 & 115.5 \\
Sugarcane $^{e}$ & India & 60.7 & 4522 & 95.4 \\
Corn $^{e}$ & US & 9.4 & 3751 & 79.1 \\
Corn $^{e}$ & China & 5.0 & 1995 & 42.1 \\
Cassava $^{e}$ & Brazil & 13.6 & 1863 & 39.3 \\
Cassava $^{e}$ & Nigeria & 10.8 & 1480 & 31.2 \\
Rapeseed $^{b}$ & China & 1.7 & 726 & 23.9 \\
Rapeseed $^{b}$ & Canada & 1.5 & 641 & 21.1 \\
Soybean $^{b}$ & US & 2.7 & 552 & 18.2 \\
Soybean $^{b}$ & Brazil & 2.4 & 491 & 16.1 \\
\hline
\end{tabular}

${ }^{b}$ Biodiesel, ${ }^{e}$ ethanol. Crop yields: 2003-2005 average (FAOSTAT 2005, http://faostat.fao.org/). Conversion yields: corn, $0.399 \mathrm{~L} / \mathrm{kg} ;{ }^{62}$ cassava, $0.137 \mathrm{~L} / \mathrm{kg} ;{ }^{44}$ soybean $0.205 \mathrm{~L} / \mathrm{kg} ;{ }^{14}$ rapeseed, $0.427 \mathrm{~L} / \mathrm{kg} ;{ }^{3}$ sugarcane, calculated, total sugarcane production of 379.7 million $\mathrm{Mg}$ in $2005,{ }^{111} 53.6 \%$ of Brazilian sugarcane produced ethanol in $2005,{ }^{18}$ producing 15,153 million liters of ethanol: ${ }^{111}$ Brazil's average efficiency is 74.5 liters of ethanol per $\mathrm{Mg}$ of sugarcane; oil palm, calculated based on $20 \%$ of harvested mass is crude oil, 1:1 conversion of crude palm oil to biodiesel (personal communication. Dr. Ma Ah Ngan, Malaysian Palm Oil Board; Malaysia), and the density of palm oil is $0.87 \mathrm{~kg} / \mathrm{L}{ }^{112}$ Gross energy yield: Lower heating value of ethanol $21.1 \mathrm{MJ} / \mathrm{L}^{113}$ or biodiesel $32.9 \mathrm{MJ} / \mathrm{L}^{114} \times$ Conversion yield $\times$ Crop yield. No co-product energy credits are included.
Global soybean production area has undergone a recent large expansion. Much of this expansion has occurred in Brazil and further expansion will come at the expense of rainforest, which threatens biodiversity in the Amazon ${ }^{9,50-52}$ and Cerrado ecozones. ${ }^{53}$ Soybean expansion is also driving deforestation in the Chaco region in Argentina. ${ }^{54}$ Because land use change accounted for $\sim 20 \%$ of global GHG emissions during the 1990's, some authors have argued that the direct and indirect effects of biofuel crop production area expansion on deforestation and associated GHG emissions must be considered in LCG studies of biofuel systems. ${ }^{10,11,55}$

\subsubsection{Oil Palm-Biodiesel}

Like soybean, there has been a rapid expansion of global oil palm production area. Most of this expansion is occurring in Malaysia and Indonesia, ${ }^{56}$ which account for $80 \%$ of global production, at the expense of rainforest habitat that supports a number of endangered plant and animal species. ${ }^{57,58}$ In contrast to soybean, oil palm gives very high oil yield per hectare, which makes this system the most productive of all biofuel systems in terms of gross energy (Table II). A recent LCE study of oil palm-biodiesel found an NER of $6.0-10.3$ for six individual oil palm mills in Brazil and Columbia, ${ }^{59}$ which is similar to the efficiency of sugarcane-ethanol. Fertilizer was found to represent the single largest energy input for the feedstock component of the production life cycle. A notable strength of this study is its focus on the efficiency of specific oil palm areas and associated biodiesel production facilities, which has a smaller margin of error than studies based on aggregate regional or national data.

An inventory of the direct and indirect GHG emissions from the Malaysian oil palm industry found that it is a net emitter of GHGs when deforestation to establish these plantations is considered in the analysis. ${ }^{60}$ In contrast, oil palm plantations for biodiesel not established by deforestation may contribute to a net reduction in GHG emissions because of a high NER, and net $\mathrm{C}$ sequestration in soil and the large standing biomass of this perennial crop. Despite the positive GHG mitigation from established plantations, widespread expansion at the expense of rainforest would release large $\mathrm{C}$ stocks and could make the oil palm-biodiesel industry a net emitter of GHGs relative to conventional fuels. ${ }^{60}$

\subsection{Comparison of Established Biofuel Systems}

A number of conditions must be met to allow accurate comparison of LCA results from different studies of biofuel systems that utilize the same feedstock, such as corn grain-ethanol. Equivalent system boundaries, comparable input and output categories, and consistent use of high or low heating values for all fossil fuel inputs and biofuel 
products are essential for such comparisons. ${ }^{4}$ Equivalent energy values and methods of accounting for co-product energy credits and GHG off-sets also are critical.

Comparisons between biofuel systems that use different feedstock sources are perhaps more problematic because of differences in feedstock production and conversion to biofuel and co-products. Despite these differences, use of standardized LCA methods makes such comparisons possible. For example, co-product outputs of electricity (sugarcane-ethanol) or soybean meal (soybeanbiodiesel) can be compared on an equal basis by estimating their embodied energy value using the displacement method.

Gross energy yield per unit of land is easier to calculate than NER, NEV, or NEY because energy inputs and associated GHG emissions are not quantified. While not an appropriate metric to estimate energy efficiency or environmental impact, gross output quantifies the total energy a biofuel system can potentially contribute to a regional or national transportation fuel system based on the land area available to produce the feedstock crop. Among the major biofuel crops, gross energy yield is greatest for Malaysian oil palm and smallest for Brazilian soybean with a 10 -fold difference between the two (Table II). Among the major established biofuel systems, only oil palm-biodiesel, sugarcane-ethanol, and advanced corn grain-ethanol systems achieve high gross energy yields and provide a substantial reduction in GHG emissions (Fig. 2).

Assuming strong national commitments to prevent large-scale crop expansion into sensitive ecosystems, ${ }^{9}$ the degree to which biofuel can replace petroleum-based transportation fuels will depend on gross energy yields from biofuel systems. Therefore, high yielding biofuel cropping systems are the key to meeting both demand for biofuels and human food while minimizing the need for a large expansion of crop area into natural ecosystems. ${ }^{26}$

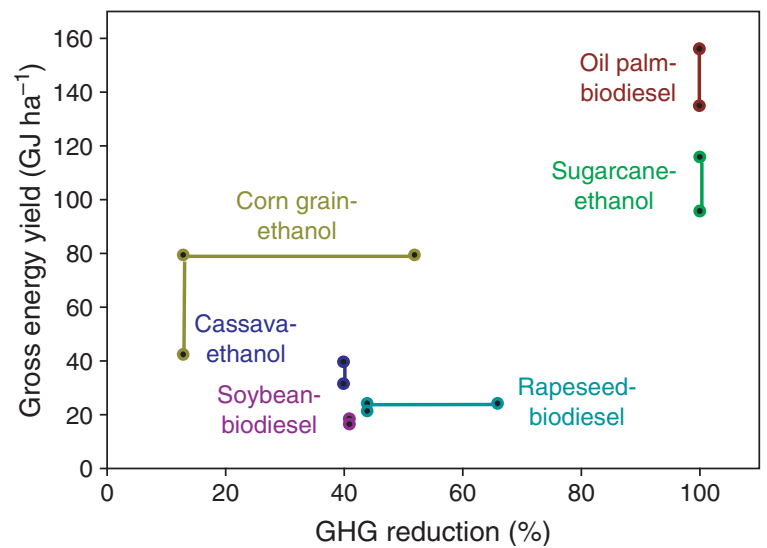

Fig. 2. Gross energy yield and net GHG reduction estimates for foodcrop biofuel systems. Gross energy yields are based on estimates from Table II; two gross energy yield estimates are provided for each crop based on the average crop yields of the two largest producing countries. Net GHG reductions are taken from estimates in Figure 1.

\section{ADVANCES IN THE PERFORMANCE OF CORN GRAIN-ETHANOL SYSTEMS}

Rapid expansion of the USA corn grain-ethanol industry is enabling adoption of innovative technologies that improve biorefinery efficiency. ${ }^{26}$ Hence, there is a critical need for LCA methods for assessment of evolving biofuel systems to quantify the impact of these improvements on energy yield, efficiency, and GHG mitigation.

Energy use at the biorefinery is a critical parameter to accurately assess industry performance. A recent study used 13.9 $\mathrm{MJ} \mathrm{L}^{-1}$ of thermal energy required for an average U.S. corn grain-ethanol biorefinery, which accounted for $67 \%$ of life-cycle energy input for corn grain-ethanol. ${ }^{4}$ This biorefinery energy efficiency estimate was based on data from 2001 that represented an arithmetic mean of energy requirements for both wet- and dry-mill ethanol plants, average energy inputs from natural gas and coal, and average co-product processing with a majority of plants using energy to dry distillers grains. ${ }^{32}$ In contrast, the efficiency of a current state-of-the-art corn grainethanol production facility with a dry-grind milling process and natural gas as a source of thermal energy is estimated at 9.0 $\mathrm{MJ} \mathrm{L}^{-1}\left(32,330 \mathrm{Btu} \mathrm{gal}^{-1}\right)$, which decreases

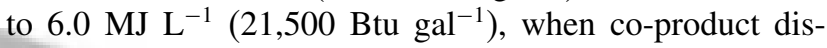
tiller's grains are not dried and fed wet to livestock feeding operations within a $100 \mathrm{~km}$ radius of the ethanol plant. ${ }^{61}$ Omitting the drying of distiller's grains results in a 57\% reduction in thermal energy use at the biorefinery compared to previous estimates used in recent studies. The latest industry survey confirms these smaller estimates of energy requirements in recently built dry-mill ethanol biorefineries. ${ }^{62}$

A number of other biorefinery innovations for corn grain-ethanol systems are under development to further increase energy efficiency and reduce GHG emissions. "Raw"/"cold" starch technology uses enzymes for starch degradation at lower temperatures, which can significantly reduce energy needs and associated GHG emissions. ${ }^{27,63}$ Although this technology is already commercially available, enzymes are still too expensive for broad commercial use. A "closed-loop" using biogas can substitute the majority of natural gas at the biorefinery-in this system, wet distiller's grains are fed to cattle in an on-site feedlot with slotted floors that capture manure and urine for anaerobic digestion. Biomass can be used for co-generation of heat and power at the biorefinery to replace purchased electricity from a local utility and natural gas or coal-derived energy inputs, which is estimated to reduce life-cycle GHG emissions by $52 \%$ compared to gasoline (Fig. 1) ${ }^{64}$ Wind, hydro, and solar energy are potential sources of electricity, and if a biorefinery is located near a nuclear power plant, steam generated from these facilities could be used as a biorefinery energy source. All of these options would substantially increase life-cycle energy efficiency or reduce GHG emissions of corn grain-ethanol by achieving 
substantial reductions in fossil fuel energy consumption at the biorefinery.

In addition to technology innovations at the biorefinery, crop yields and production efficiencies have been steadily increasing due to genetic improvement of biofuel crops and advances in agronomic management. ${ }^{65-67}$ For example, US corn yields have been increasing at a linear rate of $112 \mathrm{~kg} \mathrm{ha}^{-1} \mathrm{yr}^{-1}$ since 1966 , while $\mathrm{N}$ fertilizer efficiency, quantified by the amount of grain produced per unit of applied nitrogen, has risen by nearly $40 \%$ since 1980. There are, however, large regional differences in crop yields and requirements for production inputs because of differences in soil properties, climate, and access to irrigation. In 2003-2005, for example, the highest average county-level corn yield in the U.S. was $13.6 \mathrm{Mg} \mathrm{ha}^{-1}$, which was $43 \%$ greater than the Corn Belt average $\left(9.5 \mathrm{Mg} \mathrm{ha}^{-1}\right)$ and $66 \%$ greater than the national average corn yield of $8.2 \mathrm{Mg} \mathrm{ha}^{-1}$ (Fig. 3). Life-cycle assessment of corn grain-ethanol is further complicated by the fact that corn is produced with energy-intensive irrigation in the drier Western states (e.g., NE, KS, CO, TX), but is almost entirely grown under rainfed conditions in the Eastern Corn Belt states. Offsetting the disadvantage of irrigation energy requirements is the higher feedlot cattle density in these semi-arid Western states, which allows use of wet distiller's grains as feed in local feedlots and saves energy for drying at the biorefinery and for co-product transportation. ${ }^{36}$

Because crop yield and input requirements have a large impact on net energy yield, efficiency, and GHG emissions of a biofuel system, certifying GHG emissions for an individual biorefinery will require assessment of the actual crop production systems that supply the feedstock. To date, however, most life-cycle studies of biofuel systems have been based on average crop yields and crop management statistics for the entire Corn Belt, or on national averages (Table I).

Taken together, the rapid improvements in corn grainethanol technology promise the potential to make substantial improvements in NEY and GHG mitigation potential. In fact, it should be feasible to make corn grain-ethanol systems approach the net energy yields and GHG reduction potential of current sugarcane-ethanol systems in Brazil, and the hypothetical values for lignocellulosic systems based on perennial grass crops such as switchgrass.

\subsection{Greenhouse Gas Emission Reductions Accounting and Trading}

Rising atmospheric concentrations of $\mathrm{CO}_{2}$ and other GHGs and the associated threat of climate change has led to global discussion about policies and incentives to reverse these trends. ${ }^{1,68}$ The goal of reducing net GHG emissions from a given industry requires a change in practices that lead to a measurable reduction in life-cycle emissions below the prevailing base-line determined by the comparable petroleum-derived fuel. Reductions from this baseline must account for all direct and indirect GHG emissions generated across the biofuel production life-cycle. In producing corn grain-ethanol, for example,

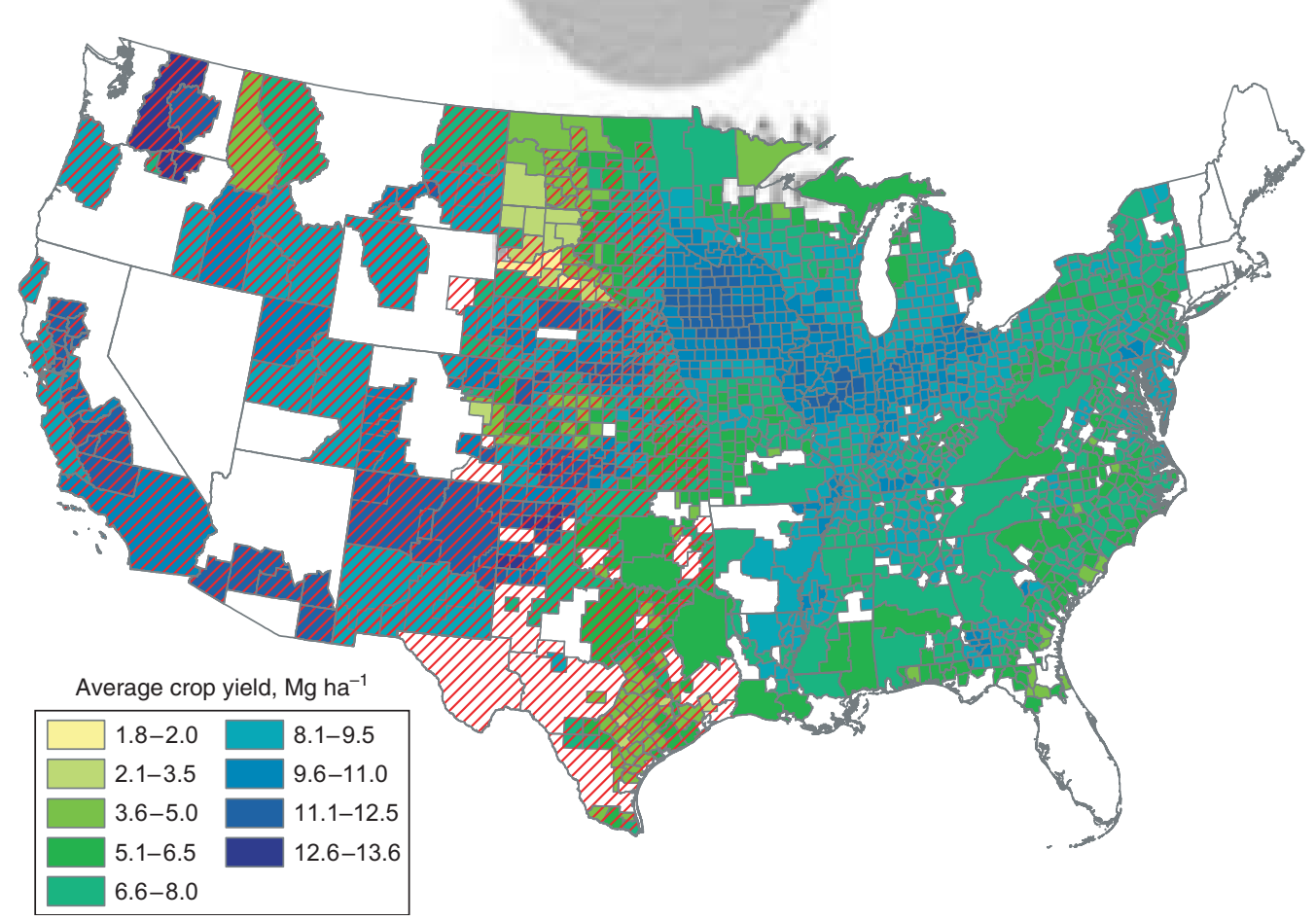

Fig. 3. USA corn grain yield (2003-2005 average) by county. Red-hatched region represent counties where irrigated corn production occurs (2001 data). Source: National Agricultural Statistics Service, USDA. 
$40-80 \%$ of life-cycle biofuel emissions come from the biorefinery and co-product processing while the remaining $20-60 \%$ of emissions are produced in the crop production phase. Hence, both stages of production must be accurately assessed.

If national GHG emission reductions are mandated by legislation, as they are in Europe under the European Union's Emissions Trading Scheme, ${ }^{68}$ an emissions capand-trade system could add an additional income stream for the biofuel industry. ${ }^{69,70}$ Implementation of the European Union's emissions trading market has been constrained, however, by a lack of facility-specific data and a scarcity of sector-specific emission models. ${ }^{68}$ To fill that gap for biofuels, LCA software tools are needed. While several models have been developed to estimate life-cycle emissions for corn grain-ethanol systems, they do not allow customization for specific biorefineries, co-product feeding and associated feedstock supply and provide a transparent assessment of all input parameters and output metrics in a user-friendly interface. ${ }^{5}$ In contrast, the Biofuel Energy Systems Simulator (BESS model, www.bess.unl.edu) was designed to be used as a certification tool for assessing the performance of an individual biorefinery and feedstock supply. It has a user-friendly graphic interface and reporting system to estimate the NER and NEY, natural resource requirements, petroleum use, GHG emissions intensity and GHG-credits for a specific ethanol biorefinery, co-product utilization scheme, and corn production zone. ${ }^{71}$ All input and internal parameters are modifiable as appropriate for a specific system with regard to: (a) crop yields, management, production inputs, (b) biorefinery energy sources, co-product processing and transport, (c) feeding of coproducts and cattle performance, and an option for linkage with a closed-loop cattle feedlot and anaerobic digestion system (developed with PRIME Biosolutions, Omaha, $\mathrm{NE}$ ). The model also provides baseline scenarios for average corn grain-ethanol systems based on fully-documented default values for biorefinery operation and crop production obtained from the best available estimates from government databases and scientific publications.

\section{LIFE CYCLE ASSESSMENT OF EMERGING BIOFUEL SYSTEMS}

In addition to the established sugar, starch, and oil seed biofuel systems, a number "second generation" biofuel systems are currently being developed. For example, emerging lignocellulosic biofuel systems will utilize crop residues or switchgrass biomass. Life cycle assessments of such systems currently rely on laboratory- or pilot-scale production data. Extrapolation of results to commercialscale deployment must be made with caution because of multiple unknowns that introduce significant uncertainty in the estimation of life-cycle energy efficiencies and GHG emissions. The challenge is to obtain reasonable estimates for each phase in the life-cycle production process as discussed in the following examples for biochemical and thermochemical cellulosic biofuel systems.

\subsection{Cellulosic Ethanol; Biochemical Conversion}

Lignocellulosic biomass is widely regarded as the optimal feedstock for ethanol production because, in theory, it would not compete with food crops. Cellulosic crops can often be grown on marginal land not suited for intensive grain production, and the abundance of cellulose in the biosphere would enable an ethanol production capacity far greater than for biofuels derived from food crops alone. ${ }^{72}$ Cellulosic ethanol is not currently produced at a large commercial scale in biorefineries with annual biofuel output of $>5 \mathrm{ML}$, but several companies currently operate pilot scale facilities and plan to develop commercial scale biorefineries of 5 to $150 \mathrm{ML}$ annual capacity within two to three years using wood chips, prairie grasses, and crop residues. ${ }^{17}$ In contrast, recently built corn grain-ethanol plants and those currently under construction typically have annual production capacities ranging from 150 to $450 \mathrm{ML}$.

Cellulose is a polysaccharide composed of glucose that is incorporated into plant cell walls and provides the structural rigidity for plants and trees. Cellulose polymers are condensed into microfibrils, which are intertwined with heteropolysaccharides (composed of five- and six-carbon sugars) called hemicelluloses and pectins. Complex lignin polymers of phenylpropaniod then surround the carbohydrates, creating a dense structural matrix comprised of $\sim 38 \%$ cellulose, $\sim 26 \%$ hemicellulose, and $\sim 19 \%$ lignin. $^{73}$ Lignocellulose has evolved to be highly resistant to attack from herbivorous organisms or by microbes and their degradation enzymes. ${ }^{74}$

Biochemical conversion of cellulose to ethanol requires three critical steps:

(1) pre-treatment,

(2) enzymatic saccharification, and

(3) fermentation. ${ }^{17,74,75}$

Enzymes under development for saccharification include cellulases, hemicellulases, and accessory enzymes, but their cost is currently a major factor inhibiting large-scale commercialization of cellulosic ethanol production. ${ }^{17,75}$ Whereas typical fermentation organisms can efficiently utilize six-carbon sugars (e.g., glucose), the development of organisms that can effectively ferment both fiveand six-carbon sugars produced from lignocellulose has yet to be successful for large-scale commercial use. ${ }^{17,75}$ Moreover, the mixture of sugars and organic acids produced during pretreatment inhibits both enzymatic digestion and fermentation, further complicating the cellulosic ethanol conversion process. Recent laboratory developments have been shown to improve processing of corn residue to yield nearly $100 \%$ of theoretical glucose content and $>90 \%$ of xylose content using steam pretreatment, $\mathrm{SO}_{2}$ acid catalysis, and subsequent hydrolysis with cellulases, $\beta$-glucosidases, and xylanases. ${ }^{76}$ It is now critical 
to demonstrate that such mixtures of sugars and organic acids can be fermented effectively. Even with emerging improvements in conversion methods, however, some observers predict that mature technology for large-scale deployment of cellulosic ethanol production is at least 10 years away. ${ }^{74,75}$

\subsubsection{Crop Residue Cellulosic Ethanol}

Global production of crop residues has been estimated at 2.8 billion $\mathrm{Mg} \mathrm{yr}^{-1}$ for cereals (74\% of all crop residues), having an energy equivalent of 52 exajoules $\left(10^{18} \mathrm{~J}\right) .^{77}$ Wheat straw is being evaluated as a cellulosic feedstock in Europe and the USA; approximately 80 million $\mathrm{Mg} \mathrm{yr}^{-1}$ of wheat residue is produced in the USA. Abengoa Bioenergy will begin using wheat straw as a feedstock in Salamanca, Spain, in what is proposed to be the world's first largescale $\left(5 \mathrm{ML} \mathrm{yr}^{-1}\right)$ commercial cellulosic ethanol facility. Iogen Corporation is using wheat straw for their cellulosic ethanol facility of $\sim 3.8 \mathrm{ML} \mathrm{yr}^{-1}$ in Ottawal, Canada and building a larger commercial-scale facility using wheat straw in Idaho.

Corn residue is another abundant crop residue under evaluation as a feedstock for cellulosic ethanol. More than 250 million $\mathrm{Mg}$ of corn residue are produced in the US each year. ${ }^{77}$ Abengoa Bioenergy will soon begin operation of a pilot scale facility that utilizes corn residue for cellulosic ethanol in York, Nebraska. Commercial-scale facilities are also under development with grant funding from the US Department of Energy in Iowa (Poet, LLC, Sioux Falls, SD) and Kansas (Abengoa Bioenergy).

The life-cycle energy efficiency of corn residue collection and conversion to cellulosic ethanol has received limited attention. The most comprehensive LCA performed to date analyzed a hypothetical system in Iowa using four different models to estimate the impact on
(i) soil $\mathrm{C}$,
(ii) soil erosion,
(iii) energy and GHG mitigation, and
(iv) economic performance. ${ }^{78}$

Crop yields and residue removal rates were based on average corn yields in several Iowa counties as opposed to regional or national yield averages. Maximum residue removal rates were determined to ensure that estimated erosion rates were below soil degrading thresholds; up to $70 \%$ removal was allowed for no-till production systems. Cellulose-to-ethanol conversion efficiency estimates were obtained from laboratory-scale data generated by scientists at the National Renewable Energy Laboratory (NREL) in Golden, Colorado. ${ }^{79}$ Overall, the estimated lifecycle fossil energy use and GHG emission reductions for cellulosic ethanol from corn residue were both reduced by approximately $100 \%$ compared to gasoline. However, these estimates excluded biorefinery infrastructure costs, which are likely substantial because capital costs for building a cellulosic ethanol facility are estimated to be $\sim 5$-fold greater than for corn grain-ethanol. ${ }^{80}$ Likewise, allocation of energy inputs and GHG emissions between corn grain and residue was unbalanced. Except for the energy embodied in the nutrients removed with the harvested biomass and the additional fuel energy required for residue harvest, all other energy inputs for corn production were assigned only to grain production. A more reasonable approach would equally divide energy costs for all crop production management operations and inputs between the grain and residue because both represent approximately $50 \%$ of the aboveground biomass. Adjusting for these omissions would substantially reduce the net GHG emission reduction and fossil fuel energy use of corn residue ethanol as estimated in this study and would improve these values for corn grain-ethanol in systems that utilized corn residue for biofuel production. Another study examined the life-cycle efficiency of corn residue cellulosic ethanol in Ontario, Canada, and estimated $65 \%$ reduction in GHG emissions. ${ }^{81}$ Like the Iowa study, these authors allocated $100 \%$ of crop production input energy to grain production alone and used experimental data from NREL for conversion efficiency. ${ }^{79}$

Crop residue removal is associated with a number of environmental concerns such as greater soil erosion, the need to replace nutrient losses removed in the biomass, ${ }^{82}$ and reduced water use efficiency due to higher soil evaporation and reduced snow melt retention. ${ }^{83,84}$ Decreasing soil organic matter (SOM) levels associated with residue removal contribute to reductions in soil quality and crop yields. ${ }^{77,85,86}$ Residue removal that reduces SOM levels would also contribute net $\mathrm{CO}_{2}$ release to the atmosphere. ${ }^{86}$ Corn residue removal rates to achieve acceptable levels of soil erosion and soil moisture conservation have been estimated recently for the Corn Belt; results suggest that 100 million $\mathrm{Mg}$ of residue could be collected annually under universal no-till in Illinois, Iowa, and Nebraska. ${ }^{87}$ Others have provided more conservative estimates of the corn residue that can be removed without causing a reduction in soil organic C. ${ }^{88,89,90}$

Because of the potential negative environmental and GHG impacts from residue removal, some argue that widespread cellulosic ethanol production from corn residue is not sustainable and, instead, cellulosic ethanol should be supported by dedicated energy crops with substantially higher biomass yields. ${ }^{77}$

\subsubsection{Switchgrass Cellulosic Ethanol}

Switchgrass (Panicum virgatum L.) is native to North America and has been evaluated as a potential cellulosic ethanol feedstock by the US DOE and US Department of Agriculture. This work has identified a number of desirable characteristics for a biomass feedstock. ${ }^{91}$ It can be grown on a wide range of soils and across a wide geographic area. ${ }^{92}$ It is estimated that 60 million hectares of marginal land could be used for energy crops in the USA, and switchgrass is adapted for much of this area. ${ }^{93}$ Unlike crop 
residues, switchgrass can be harvested with conventional forage harvesting machinery and baled for transportation and storage. As a perennial species, it can be harvested annually for ten years or more without reseeding. ${ }^{91}$ Singlecut yields of the 'Alamo' variety across the Great Plains and Southeastern USA averaged $12-19 \mathrm{Mg} \mathrm{ha}^{-1} \mathrm{yr}^{-1}$. The yields of rainfed switchgrass in North Dakota, however, fluctuated between 3.2 and $12.5 \mathrm{Mg} \mathrm{ha}^{-1}$ in consecutive dry and wet years. ${ }^{94}$ As a perennial grass species with a large root system, switchgrass systems have potential for soil C sequestration. ${ }^{92,95,96}$

A number of life-cycle studies of switchgrass cellulosic ethanol have found favorable energy yield, efficiencies and GHG mitigation. Using the GREET model, Wang et al. (1999) predicted that switchgrass ethanol would reduce GHG emissions by $84-86 \%$, compared to gasoline. ${ }^{30} \mathrm{In}$ contrast, Pimentel and Patzek assess this system less favorably, estimating that $50 \%$ more fossil energy would be needed than produced in the ethanol, similar to their conclusions concerning corn grain-ethanol and soybeanbiodiesel. ${ }^{29}$ Pimentel and Patzek's results assume that conversion energy is provided by an outside source (coal or natural gas), whereas the GREET model study assumed the lignin portion of the biomass is burned to generate steam and electricity, thus providing a carbon-neutral energy source for biomass processing. ${ }^{30}$ Steam and electricity used in the conversion of cellulose to ethanol accounts for about $60 \%$ of life-cycle energy inputs according to Pimentel and Patzek. Switchgrass for cellulosic ethanol in Ontario, Canada, was estimated to reduce life-cycle GHG emissions by $57 \%$ compared to gasoline. ${ }^{81}$ The Ontario analysis assumed that the lignin would be burned to generate heat and steam for the ethanol conversion process, and used biomass-to-ethanol conversion yield data from corn residue because of the similarity of feedstock composition. ${ }^{79}$ The Ontario study also excluded energy costs embodied in biorefinery infrastructure from their assessment.

Estimates of net energy yield, efficiency and GHG mitigation from all of these hypothetical switchgrass ethanol systems should be viewed with caution because it is impossible to validate key underpinning assumptions with data from commercial-scale production systems-both for feedstock and biorefinery operations. However, as first generation large-scale cellulosic ethanol systems are established and conversion processes are optimized, greater precision in LCAs will be possible.

\subsection{Fischer-Tropsch Biofuel}

Biomass can also be converted to liquid fuel via thermochemical processes. ${ }^{97}$ The Fischer-Tropsch (F-T) thermochemical synthesis can utilize a wide range of feedstocks. It is currently used to convert coal to liquid fuels in South Africa, and new facilities are planned that will use biomass in Germany. ${ }^{98}$ The F-T process begins by gasifying biomass into syngas consisting of hydrogen and carbon monoxide, which then react via catalysts $(\mathrm{Co}, \mathrm{Fe}, \mathrm{Ru})$ to produce populations of hydrocarbons of various lengths ranging from methane $\left(\mathrm{CH}_{4}\right)$ to $\mathrm{C}_{20}$-chains. The resulting fuel has more energy than ethanol on a volume basis because it is composed of longer-chain hydrocarbons, making it more similar to petroleum-based fuels and more suitable than ethanol for pipeline transport and storage infrastructure.

Despite recent developments, F-T synthesis using biomass has only been successful on a pilot-plant scale and will require more research and development for production of high-quality biofuels. ${ }^{97}$ The lack of uniformity in the fuels produced by F-T synthesis is a key technical drawback of the conversion system. To date, the overall thermal efficiency of the conversion process is low because a portion of the biomass is used for process energy, enabling a maximum efficiency of $\sim 46 \%$. $^{97,99}$

A recent LCA study of F-T biofuel production from switchgrass using the GREET model estimated a reduction in GHG emissions of $85 \%$ compared to conventional diesel. ${ }^{100}$ In this study, synthesis products were assumed to be F-T diesel (37\%), F-T gasoline (23\%), and electricity (40\%). In another study, high-diversity low-input prairie grasses were evaluated as a feedstock for F-T biofuels, and the LCA indicated favorable life-cycle efficiencies. ${ }^{15}$ Yields of prairie grasses in this study were likely overestimated and fertilizer inputs underestimated, however, because less than $3 \%$ of the biomass was actually removed in the annual harvest from the experimental plots from which the yield estimates were made. ${ }^{101,102}$ As with cellulosic ethanol systems, both F-T LCA studies are highly speculative because F-T technologies are not yet mature and there remain many uncertainties about process efficiencies, capital investment requirements, and profitability of large-scale commercial systems.

\section{LINKAGES AMONG BIOFUEL SYSTEM PERFORMANCE METRICS}

Regional, national, and global biofuel production capacity is ultimately governed by biofuel crop yields and the amount of land and water available for biofuel crop production. Gross energy yield and NEY, and the biofuel: petroleum energy ratio are metrics that determine petroleum replacement potential for a specific feedstock crop on a land area-time basis. Together they establish the total amount of petroleum substitution that is possible, the efficiency of that substitution, and the efficiency with regard to all forms of fossil fuel energy used in the biofuel production life cycle. The ideal biofuel system will have large gross and net energy yields, and a biofuel:petroleum energy ratio that exceeds 10:1. In general, biofuel systems with a large NEY and a high biofuel:petroleum energy ratio will achieve a substantial reduction in GHG emissions relative to gasoline. 
Nitrous oxide emissions from $\mathrm{N}$ fertilizer applied in feedstock crop production is another key factor affecting net GHG emissions. ${ }^{103}$ On a mass basis, $\mathrm{N}_{2} \mathrm{O}$ is a potent GHG with a global warming potential 298 -fold greater than $\mathrm{CO}_{2} \cdot{ }^{104}$ Applied nitrogen also can be lost via leaching to groundwater and runoff to surface water bodies, which reduces water quality. In addition, $\mathrm{N}$ fertilizer represents a large proportion of the energy inputs to crop feedstock production. Hence, biofuel feedstocks that can produce high grain or biomass yields with high $\mathrm{N}$ fertilizer efficiency contribute to greater energy efficiency, reduced GHG emissions, and protection of water quality.

The potential for soil $\mathrm{C}$ sequestration provides another avenue to reduce GHG emissions from feedstock production. Net $\mathrm{C}$ sequestration occurs in a cropping system when $\mathrm{C}$ in crop residues returned to soil exceeds the amount lost from decomposition of soil organic matter and soil erosion. The excess $\mathrm{C}$ is stored in soil organic matter, and higher levels of soil organic matter contribute to improved soil quality and higher crop yields. ${ }^{86}$ Carbon sequestration is greatest in perennial grass systems such as native prairies and monoculture switchgrass. . $^{91,92,95,96}$ Some corn-based cropping systems achieve net $\mathrm{C}$ sequestration depending upon yield levels, tillage methods, and amount of crop residue removal. ${ }^{41,42,105-107}$ In addition to influencing soil $\mathrm{C}$ dynamics, no-till systems require less energy for tillage operations and keep crop residues on the soil surface, which protects against erosion.
Over-appropriation of water resources is an additional concern associated with expansion of biofuel production capacity because many of the world's major irrigated crop production areas are at risk of over-appropriation or salinization of water resources. ${ }^{108}$ In the semi-arid U.S. Great Plains, for example, biofuel crops are grown with irrigation obtained from Rocky Mountain snowmelt and the Great Plains Aquifer, both of which are threatened by overuse and chronic drought. Depletion of water resources can be avoided by investment in irrigation technologies that improve irrigation efficiency, active monitoring of groundwater and surface water body reserves, and regulation of water withdrawals. Greater irrigation efficiency also reduces energy use per unit of feedstock yield thus contributing to greater NEY and reduced GHG emissions. Water use efficiency in ethanol biorefineries has been steadily increasing due to improvements in existing facilities and because new ethanol biorefinery designs are more water efficient than older ones. ${ }^{62}$

\section{STANDARDIZATION OF LIFE CYCLE ASSESSMENT METRICS FOR BIOFUEL SYSTEMS}

There are two issues with regard to standardization. The first is choosing the appropriate metric for the goal of the assessment, and the second is the appropriate analysis framework to support the selected metric. From recent

Table III. Energy and GHG metrics used in life cycle assessments.

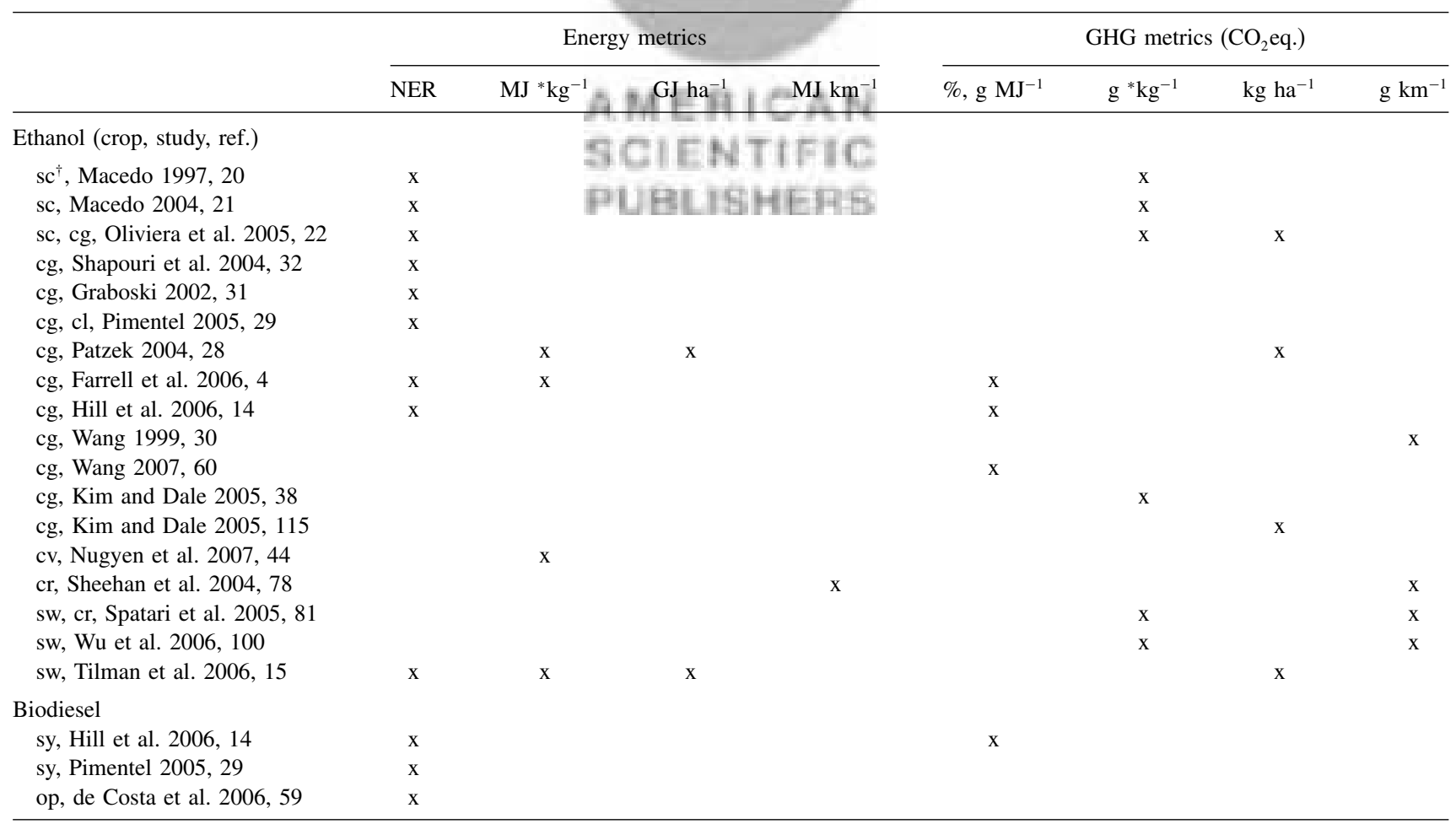

${ }^{\dagger}$ Abbreviations are in Figure 1. *Also includes per volume, $\mathrm{L}$ or $\mathrm{m}^{3}$. 
studies of food-based or cellulosic ethanol and biodiesel systems reviewed here, there is a wide range of metrics employed (Table III). The metrics used determine the energy and GHG performance of a biofuel system based on quantities of fuel produced, yield per unit land area, or vehicle distance driven. Once an appropriate metric is selected, we propose a generic framework for establishing a standardized analysis of an individual biofuel system using one type of feedstock (Table IV). This same framework may also apply to other biofuel systems using different feedstocks if the same metric applies. From our view, GHG emissions reduction $\left(\mathrm{g} \mathrm{CO}_{2} \mathrm{eq} \mathrm{MJ}^{-1}\right.$ ) and NEY (GJ ha ${ }^{-1}$ ) are two of the most informative metrics for estimating the potential for GHG mitigation and fossil fuel replacement, respectively. In some cases, other metrics may also be important, such as NEY per unit water requirement.

Standardized LCA metrics will need oversight by suitable regulatory boards. Involvement of relevant stakeholders consisting of academia, government regulators, crop producers, biofuel producers, industry associations, and environmental advocacy organizations $/$ are needed. The International Energy Agency task group 38 has

Table IV. Standardization procedure for regulatory LCA metrics for GHG and energy balances of individual biofuel systems.

LCA element

Biofuel system boundaries

Individual biorefinery facility

Input parameters: variable (e.g., regional crop yields and input rates) or constant parameters (e.g., GHG emissions factors, national averages)

Crop production system

Biorefinery co-product credits

Soil carbon emissions balance (GHG LCA only)

Nitrous oxide $\left(\mathrm{N}_{2} \mathrm{O}\right)$ emissions (GHG LCA only)

Land use change-indirect GHG emissions (GHG LCA only)
Standardization procedure

Explicit definition of system components and metrics, including an emissions inventory for each component and the entire system as given below

Serves as focus of implementing certification or regulations regarding life-cycle emissions reductions; establish inventory of inputs and outputs

Evaluate variability of input parameters and justify which are considered constant (e.g., $< \pm 20 \%$ change in parameter value within a set of systems) or variable; use most recent, directly measured values where possible

Most recent county, state, or regional data depending on the most appropriate scale and data availability for the biorefinery facility under evaluation

Based on representative co-product use for the facility in question

Based on measured changes in soil, if available, or as estimated by appropriate ecosystem models

Based on measured emissions, if available, or estimated by IPCC guidelines (Ref. [116])

Estimated using an appropriate global econometric model (Ref. [117]), depending on accepted national or international standards for allocating these effects already done previous work exploring standardized protocols for determining the GHG balances of bioenergy systems (http://www.ieabioenergy-task38.org/). Further work is underway through the establishment of Clean Development Mechanism protocols for GHG budgets by the United Nations Framework Convention on Climate Change (http://cdm.unfccc.int/). A certification board for biofuels is also needed to provide regular updates to the standard assessment protocols to ensure that they remain current with regard to adoption of new technologies. Certification schemes that employ international boards are in place for the forestry industry and organic agriculture in Europe, and coffee production in the developing world, and similar boards have been proposed for biofuels. ${ }^{109,110}$

Given large uncertainties in estimating the impact of land use change due to biofuels and associated effects on GHG emissions, there is an urgent need for research and policy analyses to improve understanding and estimation methods for these indirect effects. Emissions from land use change on a global scale due to commodity price increases in international markets, however, will be assigned on the basis of an entire biofuel system (e.g., the US corn grainethanol industry), not to an individual production facility. Therefore, GHG emissions from indirect land use change can be estimated by appropriate econometric analysis and included as a constant value in LCA models that compute the direct-effect emissions from an individual biorefinery.

Once standard LCA methods have been established, software tools can be developed for certification of an individual biorefinery and its associated local feedstock supply to allow monetization of GHG credits for emissions trading or for export into regulated markets. These software tools can provide the consistency needed for LCA standards (Table IV). Standard methods would also be useful in forward-looking "scenario" comparisons of technology options to help improve the efficiency and environmental performance of existing or planned biofuel systems, to assess potential outcomes from large-scale deployment of new biofuel technologies, and to help prioritize research and development efforts that seek to enhance the environmental and economic sustainability of biofuel systems.

\section{CONCLUSION}

Reducing reliance on imported petroleum, the potential for GHG mitigation, and the ability to produce biofuel feedstocks without negative environmental consequences are the primary justifications for expansion of biofuels. Ensuring that biofuel systems meet these expectations is crucial to maintaining public and political support for favorable government policies and incentives that foster continued growth of the biofuel industry. Appropriate LCA methods, metrics, and certification tools are critical to validate biofuel system performance relative to these expectations. Consistent life-cycle metrics are also critical for guiding investments in research, technology development, 
and commercialization to help ensure a sustainable energy future.

\section{ABBREVIATIONS}

$\begin{array}{ll}\text { \% C } & \text { Carbon } \\ \text { DOE } & \text { Department of energy } \\ \text { F-T } & \text { Fischer-Tropsch synthesis } \\ \text { GHG } & \text { Greenhouse gas } \\ \text { GL } & \text { Gigaliters } \\ \text { LCA } & \text { Life cycle assessment } \\ \text { LCE } & \text { Life-cycle energy } \\ \text { LCG } & \text { Life-cycle GHG } \\ \text { Mg } & \text { Megagrams (metric tons) } \\ \text { MJ } & \text { Megajoules } \\ \text { ML } & \text { Megaliters } \\ \text { NER } & \text { Net energy ratio } \\ \text { NEV } & \text { Net energy value } \\ \text { NEY } & \text { Net energy yield }\end{array}$

Acknowledgments: The authors thank Drs. Wally Wilhelm and Mark Liebig (USDA-ARS, Lincoln and Mandan, respectively) for comments and information about the impacts of corn residue utilization and perennial crops used for cellulosic ethanol, Maribeth Milner (University of Nebraska) for GIS analysis, and manuscript reviewers for providing useful comments.

\section{References}

1. IPCC, Climate Change 2007: Mitigation of Climate Change. Working Group III Contribution to the Intergovernmental Panel on Climate Change Fourth Assessment Report, Cambridge University Press, Cambridge, UK (2007).

2. R. K. Niven, Renew. Sust. Energy Rev. 9, 535 (2005).

3. L. Fulton, T. Howes, and J. Hardy, Biofuels for Transport: An International Perspective, International Energy Agency (2004).

4. A. E. Farrell, R. J. Plevin, B. T. Turner, A. D. Jones, M. O'Hare, and D. M. Kammen, Science 311, 506 (2006).

5. S. M. Arons, A. R. Brandt, M. A. Delucchi, A. Eggert, A. E. Farrell, B. K. Haya, J. Hughes, B. M. Jenkins, A. D. Jones, D. M. Kammen, S. R. Kaffka, C. R. Knittel, D. M. Lemoine, E. W. Martin, M. W. Melaina, J. M. Ogden, R. J. Plevin, D. Sperling, B. T. Turner, R. B. Williams, and C. Yang, A Low-Carbon Fuel Standard for California, Part 1: Technical Analysis, University of California-Berkeley (2007).

6. ISO 14040: Environmental Management-Life Cycle Assessment-Principles and Framework, International Organization for Standardization (1997).

7. J. B. Guinee, Handbook on Life Cycle Assessment, Kluwer Academic, London, UK (2002).

8. J. Dewulf and H. Van Langenhove, Renewable-Based Technology: Sustainability Assessment, Wiley, West Sussex, UK (2006).

9. R. L. Naylor, A. J. Liska, M. B. Burke, W. P. Falcon, J. C. Gaskell, S. D. Rozelle, and K. G. Cassman, Environment 49, 30 (2006).

10. J. Fargione, J. Hill, D. Tilman, S. Polasky, and P. Hawthorne, Science 29, 1235 (2008).

11. T. Searchinger, R. Heimlich, R. A. Houghton, F. Dong, A. Elobeid, J. Fabiosa, S. Tokgoz, D. Hayes, and T.-H. Yu, Science 29, 1238 (2008).
12. B. E. Dale, Biofuels Bioprod. Biorefin. 1, 14 (2007).

13. R. Hammerschlag, Environ. Sci. Tech. 40, 1744 (2006).

14. J. Hill, E. Nelson, D. Tilman, S. Polasky, and D. Tiffany, Proc. Nat. Acad. Sci. USA 103, 11206 (2006).

15. D. Tilman, J. Hill, and C. Lehman, Science 314, 1598 (2006).

16. K. A. Jacques, T. P. Lyons, and D. R. Kelsall, The Alcohol Textbook, 4th edn., Nottingham University Press, Nottingham, UK (2003).

17. B. Hahn-Hagerdal, M. Galbe, M. F. Gorwa-Grauslund, G. Liden, and G. Zacchi, Trends Biotech. 24, 549 (2006).

18. J. Goldemberg, Science 315, 808 (2007).

19. E. Smeets, M. Junginger, A. Faaij, A. Walter, and P. Dolzan, Sustainability of Brazilian Bio-Ethanol, Copernicus Institute, Utrecht University (2006).

20. I. D. C. Macedo, Biomass Bioenergy 14, 77 (1997).

21. I. D. C. Macedo, Assessment of Greenhouse Gas Emissions in the Production and Use of Fuel Ethanol in Brazil, Government of the State of São Paulo (2004).

22. M. E. D. Oliveira, B. E. Vaughan, and E. J. Rykiel, Bioscience 55, 593 (2005).

23. J. Malca and F. Freire, Energy 31, 3362 (2006).

24. J. J. Winberry, Ag. History 54, 343 (1980).

25. B.tV.tS: Reddy, S. Ramesh, P. S. Reddy, B. Ramaiah, P. M. Iich Salimath, and R. Kachapur, Int. Sorg. Mill. News. 46, 79 (2005).

26. K. G. Cassman, V. Eidman, and E. Simpson, Convergence of Agriculture and Energy: Implications for Research and Policy, The Council for Agricultural Science and Technology (2006).

27. G. H. Robertson, D. W. S. Wong, C. C. Lee, K. Wagschal, M. R. Smith, and W. J. Orts, J. Ag. Food Chem. 54, 353 (2006).

28. T. W. Patzek, Critical Rev. Plant Sci. 23, 519 (2004).

29. D. Pimentel and T. W. Patzek, Nat. Resour. Res. 14, 65 (2005).

30. M. Wang, C. Saricks, and D. Santini, Effects of Fuel Ethanol Use on Fuel-Cycle Energy and Greenhouse Gas Emissions, Argonne National Laboratory, US Department of Energy (1999).

31. M. S. Graboski, Fossil Energy use in the Manufacture of Corn Ethanol, National Corn Growers Association (2002).

32. H. Shapouri, J. Duffield, A. McAloon, and M. Wang, The $2001 \mathrm{Net}$ Energy Balance of Corn-Ethanol, Corn Utilization and Technology Conference, Indianapolis, IN, June (2004).

33. I. Boustead and G. F. Hancock, Handbook of Industrial Energy Analysis, Halsted Press, New York (1979).

34. C. F. Runge and B. Senauer, Foreign Affairs 86, 41 (2007).

35. S. Kim and B. E. Dale, Int. J. Life Cycle Ass. 7, 237 (2002).

36. T. J. Klopfenstein, G. E. Erickson, and V. R. Bremer, J. Animal Sci. (2008), in press.

37. S. Kim and B. E. Dale, Int. J. Life Cycle Ass. 11, 117 (2006).

38. S. Kim and B. E. Dale, Biomass Bioenergy 28, 475 (2005).

39. K. Paustian, W. J. Parton, and J. Persson, Soil Sci. Soc. Am. J. 56, 476 (1992).

40. W. J. Parton and P. E. Rasmussen, Soil Sci. Soc. Am. J. 58, 530 (1994).

41. J. M. Baker, T. E. Ochsner, R. T. Venterea, and T. J. Griffis, Ag. Ecosys. Environ. 118, 1 (2007).

42. S. B. Verma, A. Dobermann, K. G. Cassman, D. T. Walters, J. M. Knops, T. J. Arkebauer, A. E. Suyker, G. G. Burba, B. Amos, H. S. Yang, D. Ginting, K. G. Hubbard, A. A. Gitelson, and E. A. Walter-Shea, Ag. For. Met. 131, 77 (2005).

43. Z. Hu, G. Pu, F. Fang, and C. Wang, Renew. Energy 29, 2183 (2004).

44. T. L. T. Nguyen, S. H. Gheewala, and S. Garivait, Environ. Sci. Tech. 41, 4135 (2007).

45. G. Knothe, J. V. Gerpen, and J. Krahl, The Biodiesel Handbook, AOCS Press, Champaign, IL (2005).

46. A. C. Pinto, L. L. N. Guarieiro, M. J. C. Rezende, N. M. Ribeiro, E. A. Torres, W. A. Lopesc, P. A. P. Pereira, and J. B. Andrade, J. Braz. Chem. Soc. 16, 1313 (2005). 
47. Worldwatch Institute, Biofuels for Transportation: Global Potential and Implications for Sustainable Agriculture and Energy in the 21st Century (2006).

48. J. Sheehan, V. Camobreco, J. Duffield, M. S. Graboski, and H. Shapouri, Life Cycle Inventory of Biodiesel and Petroleum Diesel for Use in an Urban Bus, National Renewable Energy Laboratory, US Department of Energy (1998).

49. G. Knothe, Lipid Technology 17, 198 (2005).

50. B. S. Soares-Filho, D. C. Nepstad, L. M. Curran, G. C. Cerqueira, R. A. Garcia, C. A. Ramos, E. Voll, A. McDonald, P. Lefebvre, and P. Schlesinger, Nature 440, 520 (2006).

51. M. F. Simon and F. L. Garagorry, Environ. Conserv. 32, 203 (2005).

52. D. C. Morton, R. S. DeFries, Y. E. Shimabukuro, L. O. Anderson, E. Arai, F. D. Espirito-Santo, R. Freitas, and J. Morisette, Proc. Nat. Acad. Sci. USA 103, 14637 (2006).

53. C. A. Klink and R. B. Machado, Conserv. Biology 19, 707 (2005).

54. H. R. Grau, N. I. Gasparri, and T. M. Aide, Environ. Conserv. 32, 140 (2005).

55. R. E. Gullison, E. Raymond, P. C. Frumhoff, J. G. Canadell, C. B. Field, D. C. Nepstad, K. Hayhoe, R. Avissar, L. M. Curran, P. Friedlingstein, C. D. Jones, and C. Nobre, Science 316, 985 (2007).

56. Biopact, Indonesia announces biofuels budget for 2007 , September (2006).

57. L. M. Curran, S. N. Trigg, A. K. McDonald, D. Astiani, Y. M. Hardiono, P. Siregar, I. Caniago, and E. Kasischke, Science 303, 1000 (2004).

58. B. Goossens, L. Chikhi, M. Ancrenaz, I. Lackman-Ancrenaz, P. Andau, and M. W. Bruford, Plos Biology 4, 285 (2006).

59. R. E. da Costa, E. E. Silva Lora, E. Yanez, and E. A. Torres, The Energy Balance in the Production of Palm Oil Biodiesel-Two Case Studies: Brazil and Colombia, World Bioenergy Conference \& Exhibition, Jönköping, Sweden, May-June (2006).

60. M. B. Wahid, C. K. Weng, C. Y. May, and C. M. Chin, J. Oil Palm Res. (2006), Special Issue-April.

61. Energy and Environmental Analysis, Baseline Energy Consumption Estimates for Natural Gas and Coal-Based Ethanol Plants-The Potential Impact of Combined Heat and Power (CHP), Combined Heat and Power Partnership of the US Environmental Protection Agency (2006).

62. H. Shapouri and P. Gallagher, USDA's 2002 Ethanol Cost-ofProduction Survey, US Department of Agriculture (2005)

63. P. Wang, V. Singh, H. Xue, D. B. Johnston, K. D. Rausch, and M. E. Tumbleson, Cereal Chem. 84, 10 (2007).

64. M. Wang, M. Wu, and H. Huo, Environ. Res. Lett. 2 (2007).

65. D. N. Duvick and K. G. Cassman, Crop Sci. 39, 1622 (1999).

66. J. E. Specht, D. J. Hume, and S. V. Kumudini, Crop Sci. 39, 1560 (1999).

67. K. G. Cassman, A. Dobermann, and D. T. Walters, Ambio 31, 132 (2002).

68. A. D. Ellerman and B. K. Buchner, Rev. Environ. Econ. Pol. 1, 66 (2007).

69. US Congressional Budget Office, Trade-Offs in Allocating Allowances for $\mathrm{CO}_{2}$ Emissions (2007).

70. A. K. McElroy, Ethanol Producer Mag. 13, 142 (2007).

71. A. J. Liska, H. S. Yang, D. T. Walters, V. Bremer, G. Erickson, T. Klopfenstein, R. Koelsch, D. Kenny, P. Tracy, and K. G. Cassman, 23rd International Fuel Ethanol Workshop \& Expo, St. Louis, MO, June (2007).

72. U.S. DOE, Breaking the Biological Barriers to Cellulosic Ethanol: A Joint Research Agenda, US Department of Energy (2006).

73. D. Lee, V. N. Owens, A. Boe, and P. Jeranyama, Composition of Herbaceous Biomass Feedstocks, Sun Grant Initiative, South Dakota State University (2007).

74. M. E. Himmel, S. Y. Ding, D. K. Johnson, W. S. Adney, M. R. Nimlos, J. W. Brady, and T. D. Foust, Science 315, 804 (2007).
75. G. Stephanopoulos, Science 315, 801 (2007).

76. K. Öhgren, R. Bura, J. Saddler, and G. Zacchi, Bioresour. Tech. 98, 2503 (2007).

77. R. Lal, Environ. Int. 31, 575 (2005).

78. J. Sheehan, A. Aden, K. Paustian, K. Killian, J. Brenner, M. Walsh, and R. Nelson, J. Ind. Ecol. 7, 117 (2004).

79. A. Aden, M. Ruth, K. Ibsen, J. Jechura, K. Neeves, J. Sheehan, B. Wallace, L. Montague, A. Slayton, and J. Lukas, Lignocellulosic Biomass to Ethanol Process Design and Economics Utilizing CoCurrent Dilute Acid Prehydrolysis and Enzymatic Hydrolysis for Corn Stover, National Renewable Energy Laboratory, US Department of Energy (2002).

80. M. M. Wright and R. C. Brown, Biofuels Bioprod. Biorefin. 1, 49 (2007).

81. S. Spatari, Y. M. Zhang, and H. L. MacLean, Environ. Sci. Tech. 39, 9750 (2005).

82. R. L. Hoskinson, D. L. Karlen, S. J. Birrell, C. W. Radtke, and W. W. Wilhelm, Biomass Bioenergy 31, 126 (2007).

83. S. D. Merrill, J. M. Krupinsky, D. L. Tanaka, and R. L. Anderson, J. Soil Water Conserv. 61, 7 (2006).

84. S. D. Merrill, D. L. Tanaka, J. M. Krupinsky, and R. E. Ries, J. Soil Water Conserv. 59, 176 (2004).

85. W. W. Wilhelm, J. W. Doran, and J. F. Power, Agron. J. 78, 184 (1986).

86. W. W. Wilhelm, J. M. F. Johnson, J. L. Hatfield, W. B. Voorhees, and D. R. Linden, Agron. J. 96, 1 (2004).

87. R. L. Graham, R. Nelson, J. Sheehan, R. D. Perlack, and L. L. Wright, Agron. J. 99, 1 (2007).

88. J. Johnson, D. Reicosky, R. Allmaras, D. Archer, and W. W. Wilhelm, J. Soil Water Conserv. 61, 120 (2006).

89. J. M. F. Johnson, R. Allmaras, and D. Reicosky, Agron. J. 98, 622 (2006).

90. W. W. Wilhelm, J. M. F. Johnson, D. L. Karlenc, and D. T. Lightle, Agron. J. 99, 1665 (2007).

91. S. B. McLaughlin and L. A. Kszos, Biomass Bioenergy 28, 515 (2005).

92. S. B. McLaughlin, D. G. D. L. Ugarte, C. T. Garten, L. R. Lynd, M. A. Sanderson, V. R. Tolbert, and D. D. Wolf, Environ. Sci. Tech. 36, 2122 (2002).

93. J. Kort, M. Collins, and D. Ditsch, Biomass Bioenergy 14, 351 (1998).

94. J. D. Berdahl, A. B. Frank, J. M. Krupinsky, P. M. Carr, J. D. Hanson, and H. A. Johnson, Agron. J. 97, 549 (2005).

95. M. A. Liebig, H. A. Johnson, J. D. Hanson, and A. B. Frank, Biomass Bioenergy 28, 347 (2005).

96. D. K. Lee, V. N. Owens, and J. J. Doolittle, Agron. J. 99, 462 (2007).

97. G. W. Huber, S. Iborra, and A. Corma, Chem. Rev. 106, 4044 (2006).

98. H. Ledford, Nature 444, 677 (2006).

99. M. Prins, K. Ptasinski, and F. Janssen, Fuel Proc. Tech. 86, 375 (2004).

100. M. Wu, Y. Wu, and M. Wang, Biotech. Prog. 22, 1012 (2006).

101. M. P. Russelle, R. V. Morey, J. M. Baker, P. M. Porter, and H. J. Jung, Science 316, 1567b (2007).

102. D. Tilman, J. Hill, and C. Lehman, Science 316, 1567c (2007).

103. E. Stehfest and L. Bouwman, Nutr. Cycl. Agroecosys. 4, 204 (2006).

104. IPCC, Climate Change 2007: The Physical Science Basis, Contribution of Working Group I to the Fourth Assessment Report of the Intergovernmental Panel on Climate Change, Cambridge University Press, Cambridge, UK (2007).

105. T. O. West and W. M. Post, Soil Sci. Soc. Am. J. 66, 1930 (2002).

106. R. A. Omonode, A. Gal, D. E. Stott, T. S. Abney, and T. J. Vyn, Soil Sci. Soc. Am. J. 70, 419 (2006).

107. R. Lal, Geoderma 123, 1 (2004). 
108. R. Hassan, R. Scholes, and A. Neville (eds.), Ecosystems and Human Well-Being: Current State and Trends: Findings of the Condition and Trends Working Group of the Millennium Ecosystem Assessment, Island Press, Washington, DC (2005).

109. Global Bioenergy Partnership, A review of the current state of bioenergy development in G8 +5 countries, Food and Agriculture Organization of the United Nations, Rome, Italy (2007).

110. I. Lewandowski and A. P. C. Faaij, Biomass Bioenergy 30, 83 (2006).

111. Brasil-Ministério Da Agricultura, Produção Do Setor Sucroalcooleiro-Brasil, Departamento Da Cana-De-Açúcar E Agroenergia (2005).

112. C. Y. May, M. A. Ngan, C. K. Weng, and Y. Basiron, J. Oil Palm Res. 17, 47 (2005).
113. G. E. Totten, S. R. Westbrook, and R. J. Shah, Fuels and Lubricants Handbook: Technology, Properties, Performance and Testing, ASTM International, West Conshohocken, PA (2003).

114. S. K. Tyson, Biodiesel Handling and Use Guidelines, 2nd edn., National Renewable Energy Laboratory, US Department of Energy (2006).

115. S. Kim and B. E. Dale, Biomass Bioenergy 29, 426 (2005).

116. J. Penam, M. Gytarsky, T. Hiraishi, W. Irving, and T. Krug, 2006 IPCC Guidelines for National Greenhouse Gas Inventories. Intergovernmental Panel on Climate Change, National Greenhouse Gas Inventories Programme, IGES, Japan (2006).

117. F. van Tongeren, H. van Meijl, and Y. Surry, Ag. Economics 26, 149 (2001).

Received: 25 January 2008. Revised/Accepted: 5 April 2008.

\section{Delivered by Ingenta to:

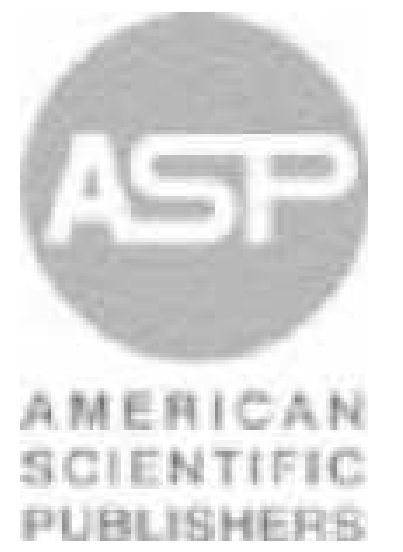

